\title{
The Double Crisis of the Welfare State and What We Can Do About It
}

\author{
Peter Taylor-Gooby \\ p.f.taylor-gooby@kent.ac.uk
}

The UK welfare state is under unprecedented attack from (1) harsh spending cuts, focussed particularly on benefits and services for women, children, low-paid people and claimers of working age, and (2) a profound restructuring programme, which is fragmenting services and embedding private provision across the state sector. It is proving surprisingly difficult for pro-welfare state actors to make a case for generous state welfare that is both inclusive and electorally attractive. This paper analyses why this is so and what can be done about it. It discusses trends in the development of the welfare state and in discourse about the problems it faces, the trilemma that pro-welfare policy-making faces, various new directions in policy and a reform programme that might help build a more inclusive welfare discourse. The arguments are necessarily compressed in a paper of this length. More extended discussion and further evidence is available in Taylor-Gooby (2013a) with background in Taylor-Gooby 2013b, c, 2012a to d and Taylor-Gooby and Stoker 2011.

\section{Context}

One account of the story of the post-war development of state welfare tells the story in terms of old and new social risks (Bonoli 2005, 2007, Taylor-Gooby 2004). Welfare states after the Second World War built on pre-war traditions and institutions to provide services to meet the common needs experienced by citizens in the course of normal everyday life. They were class collaborative in the sense that needs, provision and political support cut across middle class and working class groupings (Jessop 2002). They were highly gendered in their emphasis on health care, pensions, education and interruptions to wages through short-term unemployment, sickness and disability, geared to the needs of male workers and shaped by their assumption that care services were a free good produced by the unwaged labour of women in the home (Williams 1989). They were also nationalistic in that they were based on nation-state control of the economy to guarantee high levels of employment and implement a cohesive national social contract.

The development of more open, globalised and competitive international markets coupled with technological changes and shifts away from manufacturing towards service-sector employment increasingly individualised people's experience, undermined the trade-union collectivism that had been a powerful force for state welfare and set in train the trend towards greater dispersion of market incomes. Allied with demographic shifts and changes in family patterns and in work, the entry of large numbers of women into full-time employment and the development of women's interests as a political force, these shifts also led to the emergence of New Social Risks in three main areas:

- In relation to work, to do with access to jobs, adequate wages on which to live a normal family life, security in work once a job is found, decent working conditions 
and employment protection, education and training, extending to retraining and lifelong work and regional issues as the centres of economic activity became concentrated in the South;

- In relation to women and family life, issues of gender equality, equal opportunity and discrimination emerged, together with pressures to provide child and elder care services as private households found it increasingly difficult to meet these needs;

- In relation to the wider range of inequalities encountered in the labour market, the need for benefits and services for those of working age became pressing: an increasing proportion of workers were unable to command a 'family wage'..

The development of new social risks (NSR) alongside old social risks (OSR) has led to major changes in the structure of the welfare state. An increasing proportion of resources is directed to NSR services. In 1979 benefits for those of working age because they were on low incomes or jobless made up about 12 per cent of social security spending, and mainly consisted of benefits to unemployed people. By 2010 equivalent provision accounted for about 36 per cent, five-sixths of this directed to families to pay rent/council tax and to supplement low wages (Browne and Hood 2012, Figure 4.3).

The UK welfare state has always been dualised between services for the mass of the population (predominantly OSR provision) and services for low-income people (predominantly to meet NSRs and often means-tested). In general OSR services (health care, pensions, education and sickness/disability benefits) are rather better funded, horizontally redistributive between life states and highly popular according to the standard interview questions of the BSA (Bamfield and Horton 2009). In contrast NSR services (benefits for low waged people in work and unemployed people) are more meagrely funded, more stringently regulated and highly stigmatic. The services to meet child and elder care needs occupy a middle position, slowly developing towards a broader range of coverage but enjoying rather less public support than the established OSR services.

NSR services to meet needs for income and labour market access are relatively cheap, accounting for five to six per cent of GDP, as opposed to some 25 per cent on OSR services. They are vital in preventing poverty rising even higher than the present 18 per cent (OECD 2013) to mirror the fanning out of market inequalities, as the UK moves from a typical European pattern of inequality to one much closer to that of the US (Figure 1, Atkinson 2007). However they are at the heart of public debate about the future of the welfare state and are central to the problems encountered by those who wish to develop a politically viable prowelfare strategy.

\section{Figure 1 about here}

The lack of public sympathy with welfare for jobless people and those on low incomes (Baumberg, Bell and Gaffney 2012; Van Oorschott 2000, 2006) may be illustrated by examining the relationship between unemployment rates and attitudes to unemployment and 
to state provision to mitigate poverty (Figures 2 and 3). Unemployment fell during the late 1990 s and early years of the $21^{\text {st }}$ century to rise rapidly (along with insecurity and involuntary part-time working) after the 2008-9 financial crisis and subsequent stagnation. However endorsement of the view that benefits are too high and damage work incentives (which fell to a relatively low level during the recession of the early 1990s) has since risen steadily from 25 per of the population in 1993 to 63 per cent in 2011.

\section{Figures 2 and 3 about here}

The proportion supporting more tax-financed spending to help the poor declined from 45 per cent in 1998 to 28 per cent in 2011 despite the upward trend from 2005 in the proportion of the population in poverty. After the brief decline in 2011-12 as benefits, uprated by inflation, grew faster than stagnant wages, poverty will almost certainly rise rapidly as a result of the range of benefit cuts and indexation below inflation rates from 2013 onwards and exceed the 2010-11 level substantially by 2014-15 (Brewer et al, 2011).

The impact of public concern about these benefits for low-waged and jobless people and their families, which are a relatively minor area of public spending, is amplified by misleading perceptions of how significant they are. A series of studies including Fabian Society (2000), Horton and Gregory (2009), Taylor-Gooby (2009, ch 9), Ipsos-Mori (2013) and many others shows that most people exaggerate the scale of short-term benefit spending, often appearing to believe that it bulks as large as or larger than pension spending and is a major driving force in the growth of the welfare state. Misconceptions about taxation also play a role. The literature summarised in Taylor-Gooby (2013a ch 2 and 3) shows that most people believe that taxes on people's incomes provide by far the greater part of state revenues. In reality, income tax finances some 25.5 per cent of state spending with employees' national insurance making up 7 per cent (IFS; OECD 2013). Popular conceptions also exaggerate the progressivity of direct taxation. These assumptions support imagery of the welfare state as primarily an engine of vertical redistribution from mass to minority and minimise the horizontally redistributive role of most social spending.

\section{Explanations of benefit stigma}

In discussion of public attitudes to welfare it is helpful to distinguish short-run political factors from longer-term structural changes in society. The former include the communications by politicians (particularly but not exclusively on the right) and the majority of mass media which demonise claimers as scroungers and promote a distinction between the mass as 'strivers', seeking to take responsibility for their own lives, and a minority of outsiders who seek to live by different and exploitative rules. Baumberg, Bell and Gaffney (2012) analyse the way in which such statements reinforce stigma and build on pre-existing assumptions in the population. References to the poor as 'scroungers' have more than quadrupled since the early 2000s, despite the growing problems that people face in finding secure employment (Figure 4).

\section{Figure 4 about here}


Concern about the moral status of claimers predates recent political manoeuvres (for example, Golding and Middleton 1986, Dean and Taylor-Gooby 1992) and a full explanation must look to more structural changes. Longer run factors include processes which lead to greater social divisions and to the decline in cohesive social institutions and changes in assumptions about the values driving behaviour which moralise these divisions. The attitude data indicates long-run trends extending under very different governments. The interpretation that these are driven by changes in the circumstances of peoples' lives is reinforced by analysis of the British Social Attitudes survey from a recent Demos/JRF/IpsosMori study that indicates robust generational differences in support for spending on the poor (Ipsos-Mori 2013; see Figure 5). The implication is that an early experience of pre-war austerity fostered commitment to state welfare. Post-war affluence reduced the level of support somewhat. The uncertainty associated with the oil price hikes and recession in the 1970s weakened support further. The ascendancy of new right liberalism in the 1980s substantially reinforced suspicion of redistributive social provision.

\section{Figure 5 about here}

One of the major trends in our society is the onward march of market inequality noted earlier. This is linked to the increasing dominance of capital in relation to labour noted by Glynn (and 2006) and indicated by the fall in the share of national income received by workers from more than 70 per cent in the 1970s to about 60 per cent in the 2000s (Bailey et al. 2011). These processes coincide with the greater fragmentation of the workforce in the transition from manufacturing to service sector employment. Further factors are processes of regional and spatial development (Dorling and Ballas 2008) which increasingly segregate individuals by social status and income group. These changes help to build and are reinforced by social processes which undermine cohesive institutions such as trade unions and collective structures in the work place, common experiences of schooling and of community life, of leisure activity, in religion and in other areas of people's experience (Putnam 2000). Ethnic diversity provides another potential axis of separation. Greater flexibility in family life and geographical mobility and stronger generational differences reinforce these processes. In short social divisions grow stronger and cohesive institutions weaker.

These divisions increasingly become moralised as people experience their lives as determined by individual effort rather than as they outcome of collective forces. The 'tightening link' between education, skill and work achievement is an important factor since educational outcomes are widely believed to be primary the product of individual effort and ability rather than of opportunity support and context (Green 2013). The experience of job search and employment as primarily an individual process reinforces this. In this context the moralisation of social inequalities as attributable to individual effort, to doing what you ought to do and not doing what you shouldn't, rather than to social factors becomes normal. Failure not only leads to poverty and claiming, it is a matter of shame and stigma. This is the context which facilitates a politics of division and makes the task of designing an approach to welfare which confronts these divisions harder.

\section{The pro-welfare trilemma}


The problem faced by advocates of a generous welfare state may be thought of as a trilemma. The minimum conditions for a pro-welfare programme are that it should be inclusive (a programme that leaves out some groups on grounds not relevant to their level of welfare need is not fully a welfare programme), effective (it should actually be capable of meeting needs) and it should be electable (otherwise there is no point). Figure 6 summarises these issues in relation to short-term welfare where there are strong moral concerns about the desert of claimers. One can imagine inclusive and effective policies (for example social dividend/ citizen's wage) but such policies are unlikely to be attractive because they give money to people without test of desert. Inclusive electable policies would have to include strict rules about the application of inclusiveness to ensure that inclusion is interpreted to provide strong motives for valued behaviour and this would damage their effectiveness. Effective and electable policies (for example decent contributory benefits as currently under discussion on the centre-left) would not be inclusive.

\section{Figure 6 about here}

These constraints are much less damaging in the case of OSR services since these are highly popular. The resources necessary to sustain them can in principle be levied. There are a number of issues about the structure of and access to current provision which bear on effectiveness. A number of writers have pointed to social divisions in universal services (for example Titmuss 1955, Le Grand 2007). Addressing these issues may well require additional targeting on particular groups within common provision (for example, the Spearhead programme in health care or the Education Action Zone and Excellence in Cities initiatives in education in the early 2000s), curbs on the extent to which minorities can buy privilege through private provision and withdrawal of subsidies to such provision in pensions, schooling or health care, and programmes to expand the access of least well served groups to public provision. They can also be inclusive, and measures which address effectiveness may also reinforce inclusiveness.

\section{The double crisis: OSR services}

A substantial literature raises a different kind of problem in relation to OSR provision. A number of analyses point to pressures in this area in the longer-term future. Three factors are most commonly emphasized. First population ageing (the demographic 'time-bomb') will impose growing pressures on spending in these areas, particularly on health and social care and pensions. Secondly, the difficulty in achieving productivity gains in the service sector comparable to those in the manufacturing industry will result in a transfer of resources over time to the state sector - the 'Baumol wage effect'. Thirdly, rising public expectations will put continual pressures on state services.

It is of course hard to predict long-run future developments and these arguments may be more important in terms of their impact on current debates, as justification for immediate cut-backs on the grounds that these will prevent future problems, rather than as a guide to what will actually happen. Much depends on what happens in terms of economic growth and the UKs continuing attractiveness to migrants. For example, growth at a rate of two per cent during 
the next 50 years, rather lower than that achieved in the past half century, will produce a GDP about 2.7 times as large. Recent reports by OBR (2012) and the EC (2012) using slightly different methodologies, both produce central estimates of the projected extra demand at between four and five per cent of future GDP. These are substantial amounts, but may well be feasible in the context of greatly expanded real resources. Immigration is typically assumed to play a major role in reducing demographic imbalances in the UK.

There are perhaps three reasons why the long-run crisis in OSR services may be less pressing than is sometimes suggested:

- Analyses of productivity gains in the state human services indicate that health care and education have roughly kept pace with wage rises during the period since the early 1990s under different governments and a variety of market, managerial, targetcentred, efficiency saving, training and other regimes designed to maintain pressure on costs (cf Hardie et al 2011, Baird et al 2010, Jurd 2011). This implies that wage drift may be contained provided pressure to improve cost-efficiency in the services is maintained.

- Secondly people are willing to pay for increases; the best evidence for this is that they have paid for increased spending at a higher rate than necessary in the past. Between 1979/80 and 2007/8, under governments of very different political ideology and a range of policy regimes, total spending on health care, education and personal care rose from $£ 75.1 \mathrm{bn}$. to $£ 234.5 \mathrm{bn}$. at 2008-9 prices, a growth rate of more than four per cent (Hills 2011, 597). Private spending additional to state spending in health care and education has increased even faster, from 8.4 to 13.7 per cent of total spending in these areas (Hills 2011 Table 1). (Pension spending grew at a much more rapid rate, but is heavily influenced by policies of privatisation and by state subsidy so is omitted here).

- Thirdly the UK is in a favourable position compared to many countries in the longer term. Projected spending pressures are rather lower than in any other North-West European country during the next decade (in fact so low, due to relatively low-cost provision and more favourable demography that they do not show on the chart. In the longer term they are lower than the EU average and than in most other comparable EU members (see Figure 7 calculated from EC 2012).

\section{Figure 7 about here}

Although the OSR services account for much more money, it is in relation to NSR services that current debates have been most intense. In the current context welfare state cuts have been most stringent in relation to these services and have been particularly heavy in relation to some of the most vulnerable groups. However the cuts have been combined with restructuring across almost all areas of state activity and particularly for OSR services and these have been justified in part by concerns about future pressures in these areas. We now turn to the short-term crisis and responses to it. 


\section{An unusual crisis and a distinctive response}

The 2008-9 recession and subsequent stagnation and the policy response to it in the UK have been extensively discussed (see Yeates et al 2011 and Gough 2011 for an overview). Here we comment on how unusual UK experience is in comparison with other countries and how distinctive the UK response is along a number of dimensions.

The distinctive feature of the UK's economic experience is the depth of the 2008-9 recession and the protracted nature of the period of stagnation that has followed it (Figure 8). While other major developed countries have returned to growth and passed their 2007 level of GDP by $2010-11$, the UK remains some 2.6 per cent below that level at the time of writing and is unlikely to attain it before the 2015 election at the earliest. The Coalition government's response to economic crisis, heavily influenced by market liberal economic theories, was to cut state spending and reduce sharply the level of planned tax rises in order to reduce and eliminate the deficit and encourage a private sector-led return to growth. This strategy has not been successful and is now encountering criticism from previously supportive bodies such as IMF and OECD, although expressed in the cautious and neutral language such agencies employ (for example 'In the United Kingdom ... greater near-term flexibility in the path of fiscal adjustment should be considered in the light of lackluster private demand' IMF 2013, 49).

\section{Figure 8 about here}

The cuts are distinctive in that they detach UK public spending from its historic position at roughly the middle of the G7 group of large capitalist economies (France, Germany, Italy above, Canada, US and Japan below) and set it on a downward trajectory, after the 2007-9 burst of spending on benefits and jobs and the contraction of the GDP denominator. As argued elsewhere (Taylor-Gooby $2013 \mathrm{ch} 1$ ) this trajectory will ultimately take the UK below public spending in traditional low spenders in the US although the refusal of the economy to grow means that the year at which UK spending as a proportion of GDP will fall below that in the US is now deferred from 2015 beyond 2017 (Figure 9).

\section{Figure 9 about here}

The detail of cuts is also distinctive: focused particularly on NSR services for women, children and those on low incomes. Full details are given in the Women's Budget Group analyses of public spending (WBG 2011a, b, 2012a, b) and by Yvette Cooper's House of Commons Library calculation of the incidence of personal tax and benefit reforms (Cooper 2012). The OSR area escapes relatively lightly, officially designated as protected but in practice subjected to very substantial capital and some current cutbacks, and the raising of the pension age, while the uprating formula has become more generous. This resilience again points to the political strength of OSR services. Figure 10 covers tax and benefit changes (Joyce 2012) while Figure 11, from the 2013 Budget papers (HM Treasury 2013) also includes estimates of the impact of reforms in services in kind, assuming that the value of the service is equivalent to the cost of provision for each recipient. The graphs show how the combined impact of tax and benefit cuts bears on better off and poorest groups. Figure 9 
shows that it is greatest for households with children, and bears most discriminatingly on the poor among working age people without children. In addition cuts impact most strongly on the local government areas with the greatest of low incomes in the parts of the country where economic recovery is weakest and wage-decline greatest (HoC Library 2011).

\section{Figures 10 and 11 about here}

The cuts are also distinctive in the way in which they are ambitiously combined with major restructuring of almost all state services. The restructuring is an important feature of OSR as well as NSR reform and in this area is justified in terms of future rather than current cost savings and the need to achieve greater cost-efficiency in the long-term. It includes two main elements: the open government programme of extending principles of new public management through markets across every possible area of state activity and extending the role of private (and in some cases third sector) organisations in competition, with a strong emphasis on competition on price rather than quality (Cabinet Office 2011). Innovative payment by results schemes are also being introduced.

Further reforms to the benefits system involve simplification and greater transparency for state pensions and of short-term benefits brought together as universal credit, strengthening of work incentives and a greater role for the private sector and individual responsibility in the area of pension provision. While it is impossible to do justice to reforms of this magnitude without extended discussion, it may be noted that they involve substantial risks (see for example Taylor-Gooby 2013c), are not justified as we have seen in terms of longer-term spending pressures and so far as we can tell are likely to damage the quality of output when competition is on price rather than quality (Gaynor et al. 2010, Gaynor and Town 2012, 767).

One suggestion is that the longer term objective of the reforms, at least on the part of some in government, is to use restructuring to entrench the shift to a liberal form of state as a permanent feature of British life so that the move to a contract state spending is embedded. This may be reinforced by briefly observing the historical experience of cuts in the UK against the overall trajectory of public spending. The longer-term history of peacetime public spending in the UK as in most other countries is of a series of plateaux with the level of the plateau moved upwards (never downwards) by major shocks such as wars. Public spending in the UK hovered around ten per cent of GDP during the second half of the $19^{\text {th }}$ century, rose to 20 per cent during the Boer war, fell back to 15 per cent, then peaked at 55 per cent during World War I, fell back to around 30 per cent, reached 70 per cent during World War II and has fluctuated around 40 per cent ever since. A number of governments from 1921 onwards have implemented major cutbacks intended to address economic crises by reducing spending. In all cases the level of cuts achieved is substantially below that anticipated and in all cases spending had returned to the previous level within five years.

The key examples are the Geddes Axe of 1921-2, the 1931 Coalition government cuts, the Callaghan cut in the mid-1970s, Thatcher's rolling back of the state during the next decade, the Major cuts after the recession of the early 1990s and Brown's spending restrictions from 
2007 onwards (Figure 12: for a detailed discussion see Taylor-Gooby 2012a). Whether the process of embedding will achieve a different outcome this time is unclear Pressures to restore spending come from various directions: from local government, as in the 1920s, when it was less subject to central control than now, from concerns about civil disorder, strikes and a naval mutiny as in the 1930s, from the desire to appease voters, as in the restoration of the 1980s cuts before the 1992 election, and from the resistance of the state apparatus to contraction, as in the relatively modest 2007 Spending Review cut-backs (Dunsire and Hood 1989, Hood, Emerson and Dixon, 2010, Peacock and Wiseman 1967, IFS, 2011).

\section{Figure 12 about here}

There is also some indication that the detail as well as the volume of UK cuts is crossnationally distinctive. In most cases reported in the 2011 OECD survey of 29 western countries, cuts run across all services and are not concentrated on NSR provisions (OECD 2011).

Embedding rests on reforms which weaken both the internal and external forces helping sustain state sector resilience. Budget maximising managers, professional associations and trade unions are all weakened by privatisation and fragmentation of services. Externally, cultural support for services and their capacity to operate as social institutions that reinforce the experience of cohesion are both damaged by the fragmentation and individualisation of provision in consumerist choice between a range of profit-oriented suppliers. This reinforces the individualising context of short-term benefit reform with its stress on curbing irresponsibility and on individual effort. Thus OSR reform may be seen as a long game and one that buttresses the immediate attack on stigmatised minority services.

So far the discussion has highlighted the points that:

- Social provision in the UK is heavily and increasingly dualised between OSR and NSR services

- For long-run structural reasons reinforced by and feeding political and media communications this division moralises NSR provision, especially those areas associated with low income and unemployment

- Current government policies follow this division to embed welfare state cutbacks permanently and achieve a shift to a more individualised, liberal climate of ideas

- This involves immediate cuts in the least popular short-term services, attacking primarily benefits and services that help women, children and the poor

- It also involves major restructuring of OSR services leading to extensive privatisation, so that the welfare state does not provide an institutional experience of collective responsibility.

- The fact that the areas which are most heavily under attack are highly unpopular makes it hard for pro-welfare actors to defend social provision.

We now consider various approaches to social provision and the kind of strategy that might be able to gain popular support. 


\section{New strategies for social welfare}

Resistance to privatisation and fragmentation of OSR services goes with the grain of public attitudes and from that point of view is straightforward. The agenda of individualisation and consumerism raises issues that are more challenging and may be difficult to advance without strengthening the framework of common services. The issues of trust and the capacity of OSR services to sustain it are of major importance and are considered elsewhere (see TaylorGooby 2009 for an extended discussion).

NSR provision especially that directed at the poor presents the most intractable issues. We have argued that the problems are not simply issues of communication and of constructing an attractive political programme but of finding a way to address changes that are highly salient in current politics, but are rooted in long-run structural features of society. We also suggest that any satisfactory programme must help to build collectivism rather than entrench the social divisions which hamper current attempts to develop state welfare.

There are three main directions in recent debates about the best way forward in welfare that address these issues: contribution, predistribution and investment. The latter two areas are often linked to ideas of prevention.

Contribution offers a means of harnessing deep-seated assumptions about entitlement and reciprocity to underpin the legitimacy of welfare. A reciprocal contribution justifies entitlement (Gintis et al, 2005, ch1). The approach can be developed more broadly or more narrowly. Horton and Gregory's account of a contribution-based welfare system (2009) encompasses a wide range of useful social activities as making a contribution to society. The outcome is that activities such as caring for children, sick or elderly people, voluntary work and training to ensure one could participate in paid work in the future are credited to one's contribution record bearing entitlement for benefits, as well as the cash contributions of traditional social insurance. Bell and Gaffney (2012) discuss and partially cost a more detailed programme resting on extensions to social insurance as it existed in the recent past. Frank Field argues for a more limited strictly work-based contribution system analogous to Bismarkian social insurance (Field 2013). James Purnell and more recently Graeme Cooke (2011) have developed a salary insurance loan scheme directed specifically at relatively wellpaid workers and designed to top up benefits.

The logic of these schemes is that contribution is 'psychological gold-dust' (as Horton and Gregory put it), and insulates welfare from stigma. The downside is that they inevitably distinguish contributors from non-contributors, even in the most extensive Fabian society schemes and focus public antipathy on groups which are likely to be particularly weak in labour market attachment and vulnerable.

Predistributive programmes focus on the distribution of market incomes (Hacker 2011). For those at the bottom in low paid and often part-time work, incomes are simply insufficient to support a decent family life. One result is the massive expansion of means-tested income support programmes mainly covering the working poor, such as tax credit and housing and 
council tax benefits, from one to thirty per cent of the DWP or equivalent budget since the late 1970s (Browne and Hood 2012).

Predistribution would seek to improve wages by imposing (or in the case of some imaginative Labour party proposals) encouraging employers to pay at the Living Wage level, some 20 per cent above Minimum Wage. This involves issues of transition which would have to be staged and might differ in different industries (Pennycook 2012). The approach might also involve strengthening bargaining power through Works Councils, more representative remuneration committees and repeal of some anti-Trade Union laws (Coats 2012). More ambitious but vaguer discussion suggests controls on rent levels, utility prices and other costs that face many people and extending pre-distribution to cover social investment through training and education programmes, extending during working life, to ensure broader access to wage incomes (Carlin 2012, 2).

This approach is clearly interventionist. It sidesteps concern about the desert of claimers by focusing on market incomes and therefore on work. It would require support from a benefit system to cover those not in work.

Social investment seeks to move away from concerns about benefit entitlement by stressing the value across society of state interventions. Ben-Galim and others have estimated the net value of a universal child care programme as up to some $£ 5,000$ a year for each mother able to move from full-time childcare to full-time work on average wages as a result (Ben-Galim 2012). The sum is based on tax income and benefits saved. Even without such a shift the cost of such a programme might be much less than headline figures and it would also contribute to gender equality. A corresponding scheme for elder care might release comparable amounts (Pickard et al 2012).

Social investment seeks to justify welfare spending on economic grounds. Many activities could be seen as investment including health care, decent housing to ensure mobility and prevent disease and transport. Most work is focused on education and training where the natural experiment of the 1973 raising of the school leaving age indicates a returns exceeding 10 per cent annually to the individuals in enhanced earning capacity and a likelihood of a net social gain (Dickson and Smith 2011). It grows increasingly difficult to justify interventions on investment grounds the further one moves from education, training and child/social care, because it is uncertain how the return attributable to an intervention, for example, in social housing or wage support can be identified.

This brief discussion shows that arguments for redistributive welfare spending can be made, despite the stigma attached to provision for the poor. The case that can be made is partial and sometimes involves clear divisions typically based on real or potential attachment to the labour market. One risk is that such approaches then become gendered. This suggests that it is important to stress the more inclusive aspects of the approaches and that it is helpful to find ways to combine them in a shared narrative so that they can be pursued in concert.

\section{New social risks as a pro-welfare discourse}


The development of new social risks alongside old social risks may contribute here. A common thread in the impetus to new approaches to redistributive welfare is the realisation that for substantial numbers of people it is impossible to live a satisfactory family life on market wages. This is the point underlying the attempt by advocates of contributory approaches to suggest that activities that form part of a normal life-pattern (child and elder care, training, voluntary work) should be credited as social contribution, by predistribution approaches to make sure work at the bottom pays and by investment approaches to enable people to participate in such work through the provision of supportive services. The impact of NSR on people's lives through low wages, constrained access to training and work, issues surrounding employment protection and working conditions and parental rights, equal opportunities, the need for child and elder care and the difficulties in dealing with more complex and privatised services underlies the problems the new approaches address. This leads to a common thread which is expressed in terms of the needs for a normal family life.

This returns us to the core problem in relation to the double crisis of the welfare state. Social changes of various kinds increase anticipated pressures on services for older people and others, due primarily to long-run demographic changes and productivity handicaps in the human services sector. This leads to the suggestion that it will become very difficult to finance such services. The evidence presented earlier indicates that it will in fact be possible to sustain provision, provided economic growth returns and the pressures on spending of the past two decades are maintained.

A second set of changes has led public support for benefits for the poor to collapse just at a time when the need for such benefits is accelerating. Various responses show how it is possible to devise a strategy which might present the welfare state inclusively but in a way that would be effective and attractive to a contemporary electorate. This would involve predistribution and social investment, broadly-based contribution and a further but smaller tier of means-tested support.

One of the many issues with such an approach is that it is seeking to tackle issues rooted in social change by modifying social discourse, in traditional Marxist language to tackle issues located in the base through changes in the superstructure. This has its limits. The approach suggested may be defended on the grounds that the objective is to embark on the process of re-building more inclusive social institutions, for example those of universal child and elder care services, or common rights in the work place. These institutions could then contribute to a reframing of the issues that then might enable government to tackle the structural factors in the distribution of industrial power that lead to inequalities in the first place.

\section{Conclusion}

This paper summarises the argument of The Double Crisis of the Welfare State and What We Can Do About It. The objectives are, at a theoretical level, to analyse the current attempts to cut back and restructure state welfare in the UK and, at a practical level, to confront and perhaps reverse two common strands in the argument that expansive and generous state welfare is rendered obsolete by social change. First the book details and discusses the 
programme of cut backs and restructuring in the UK and demonstrates how exceptional it is in terms of the depth of the economic problem, the chosen public spending trajectory, the way cuts are focused on the most vulnerable groups and on women and children, in historical and cross-national comparisons and the risks taken in pursuing a simultaneous comprehensive restructuring. It argues that it is hard to understand why such a programme should be pursued unless some at least in government wish to embed a permanent stepchange in British political economy away from welfare state interventionism towards a more overtly market liberal capitalism settlement.

The second objective is to confront the twofold claims that (1) long-term population ageing and other factors make it impossible to sustain pensions and health and social care; and (2) immediate economic pressures mean that we have to cut stringently, and deep-seated changes in social circumstances lead most voters to oppose benefit spending, especially for poor people of working age, so that the welfare state that must bear the brunt of the cuts. The argument demonstrates that, provided growth is restored and provided constraints on spending of the kind pursued during the past two decades are continued, it is feasible and politically possible to devote a sufficiently large proportion of a very much larger GDP to these issues. If the provisos are not met, the problems faced by modern states dwarf those encountered in defending state welfare since their whole system of government finance is based on borrowing from a future presumed large GDP.

The problems of sustaining the much cheaper vertically redistributive services for those on low income of working age stem ultimately from shifts in social values and from public lack of sympathy with the poor. This requires new approaches to welfare that move beyond redistribution to address low wages and place the emphasis on contribution, predistribution and social investment. This approach frames the debate in a way that moves beyond tax-andspend vertical redistribution and appears politically feasible given determined leadership. It offers opportunities to construct institutions that embody the experience of collective responsibility for common problems. In the longer term this may help to shift public consciousness away from the individualism of market liberalism to a more generously inclusive approach. 
Atkinson, A. (2007) 'The Distribution of Earnings in OECD Countries', International Labour Review, 146, 2, 41-60.

Atkinson, A. (2008) The Changing Distribution of Earnings in OECD Countries, Oxford University Press, Oxford.

Bailey, J., Coward, J. and Whittaker, M. (2011) Painful Separation, Resolution Foundation, London.

Baird, A. , Haynes, J., Massey, F. and Wild R. (2010) Public Service Output, Input and Productivity: Education, ONS, London.

Bamfield, J. and Horton,. T. (2009) Understanding Attitudes to Inequality, JRF, York. Baumberg, B., Bell, K. and Gaffney, D. (2012) Benefits Stigma in Britain, TurnToUs, London.

Bell, K. and Gaffney, D. (2012) Making A Contribution, Touchstone, London.

Ben-Galim, D. (2011) Making the Case for Universal Childcare, IPPR, London.

Blanden J., Buscha F., Sturgis P., Urwin P., (2012) 'Measuring the Earnings Returns to Lifelong Learning in the UK', Economics Of Education Review, 31, 4, 501-514.

Bonoli, G. (2005) 'The Politics of the New Social Policies. Providing Coverage Against New Social Risks in Mature Welfare States', Policy and Politics, 33, 3.

Bonoli, G. (2007) 'Time Matters: Postindustrialisation, New Social Risks and Welfare State Adaptation in Advanced Industrial Democracies' Comparative Political Studies, 40, 495-520. Brewer, M., Browne, J, and Joyce, R. (2011) Child and Working Age Poverty From 2010 to 2020, IFS Commentary C121, IFS, London.

Browne, J. and Hood, A. (2012) A Survey of the UK Benefit System, BN 13, IFS, London (Updated).

Burgess, S., Propper, C. and Wilson, D. (2006) 'Extending Choice in the English Health Care System' Journal of Social Policy, 35, 4, 537-557.

Cabinet Office (2011) Open Public Services, Cm8145, HMSO, London.

Carlin, W. (2012) A Progressive Economic Strategy, Policy Network, London.

Coats, D. (2012) From the Poor Law to Welfare to Work, Smith Institute, London.

Cooke, G. (2011) National Salary Insurance: Briefing Paper, IPPR London.

Cooper, Y. (2012) Women Bear Brunt of Budget Cuts,

Http://Www.Yvettecooper.Com/Women-Bear-Brunt-Of-Budget-Cuts accessed 30 Dec 2012.

Dean, H. and Taylor-Gooby, P. (1992) Dependency Culture: The Explosion of a Myth, Harvester Wheatsheaf, Hemel Hempstead.

Dickson, M. and Smith, S. (2011) What Determines the Return to Education? CMPO Paper 11/256, Centre for Market and Public Organisation, Bristol.

Dorling, D. and Ballas, D. (2008) 'Spatial Divisions of Poverty and Wealth', in T. Ridge and

S. Wright (Eds) Understanding Poverty, Wealth and Inequality: Policies and Prospects, Policy Press, Bristol.

Dunsire, A. and Hood, C. (1989) Cutback Management in Public Bureaucracies, Cambridge University Press, Cambridge.

EC (2012) The European Ageing Report, Ecofin, Brussels.

Fabian Society (2000) Commission on Taxation and Spending, Fabian Society, London.

Field, F. (2009) Bringing an end to something for nothing welfare,

http://www.frankfield.com/latest-news/news.aspx? $p=102507$

Gaynor, M. and Town, R. (2012) Competition in Health Care Markets wp12/282, CMPO, Bristol.

Gaynor, M., Morena-Serra, R. and Propper, C. (2010) Death by Market Power, WP 10/242, CMPO, Bristol.

Gintis, H., Bowles, S., Boyd, R. and Fehr, E. (2005) Moral Sentiments and Material Interests, MIT Press, Cambridge, Mass. 
Glynn, A. (2006) Capitalism Unleashed, Oxford University Press.

Golding, P. and Middleton, S (1986) Images of Welfare, Blackwell, Oxford.

Gough, I., (2011) 'Welfare Cuts' in Farnsworth, K. and Irving, Z. (Eds 2011) Social Policy in Challenging Times, Policy Press, Bristol.

Green, F. (2013) Skills and Skilled Work, Princeton University Press, Princeton.

Hacker, J (2011) The Institutional Foundations of Middle Class Democracy, Policy Network, London.

Hardie, M., Cheers, J. Pinder, C. and Qaeser, U. (2011) Public Sector Outputs, Inputs and

Productivity: Healthcare No 5, ONS, London

Hills, J. (2011) 'The Changing Architecture of the Welfare State', Oxford Review of

Economic Policy, 27, 4, 589-607.

HM Treasury (2013) Budget 2013, HC1033,

https://www.gov.uk/government/uploads/system/uploads/attachment_data/file/188357/budget 2013 complete.pdf.pdf

HoC Library (2011) The Local Government Finance Settlement 2011-13, RP 11/16, House of Commons, London.

Hood, C., Emerson, C. and Dixon, R. (2010) Public Spending in Hard Times, ESRC Public Services Programme, University of Oxford, Oxford.

Horton, T. and Gregory, J. (2009) The Solidarity Society, Fabian Society, London.

IFS (2011) Green Budget 2011, IFS, London.

IMF (2013) International Monetary Fund World Economic Outlook Database, April 2013,

IMF, Washington.

IPPR (2012) Paying A Living Wage Could Save the UK Billions, IPPR, London.

Jessop, R. (2002) The Future of the Capitalist State, Polity.

Joyce, R. (2012) Tax and Benefit Reforms Due in 2012-13, and the Outlook for Household Incomes, BN126, IFS, London.

Jurd, A. (2011) Public Service Labour Productivity, ONS, London

Le Grand, J. (2007) The Other Invisible Hand, Princeton University Press, Princeton.

OBR (2012) Fiscal Sustainability Report July 2012, OBR, London.

Peacock, A. and Wiseman, J. (1967) The Growth of Public Expenditure in the UK, 1890-

1955, Unwin, London.

Pennycook, M. (2012) What Price a Living Wage? IPPR/Resolution Foundation.

Pickard, L. Et al (2012) Public Expenditure Costs of Carers Leaving Employment,

Http://Blogs.Lse.Ac.Uk/Healthandsocialcare/2012/04/25/Dr-Linda-Pickard-Public-

Expenditure-Costs-Of-Carers-Leaving-Employment/ accessed 30 Dec 2012.

Putnam, R. (2000) Bowling Alone, Somin and Schuster, NY.

Rothstein, B. (2005) Social Traps and the Problem of Trust, Cambridge University Press, Cambridge.

Taylor-Gooby, P. (2013a) The Double Crisis of the Welfare State and What We Can Do About It, Palgrave, Basingstoke.

- (2009) Reframing Social Citizenship, Oxford University Press, Oxford.

- (2012a) 'Root and Branch Restructuring to Achieve Major Cuts: the Social Ambitions of the Coalition', Social Policy and Administration, 46, 1 61-82.

- (2012b) 'Public Policy Futures: A Left Trilemma?' Critical Social Policy, online first October 2012.

- (2012c) $)^{6}$ Beveridge Overboard? How the UK government is using the crisis to permanently restructure the welfare state', Intereconomics, 47, 4, 224-30.

- (2012d) 'Resisting welfare state restructuring in the UK', Journal of Poverty and Social Justice, 20, 2, 119-13. 
- (2013b) 'Why Do People Stigmatise the Poor at a Time of Rapidly Increasing Inequality, and What Can Be Done about It?' Political Quarterly, 84, 1.

- (2013c) 'Riots, demonstrations, strikes and the Coalition programme', Social Policy and Society, 12, 1, 1-15, 2013.

- (Ed 2004) New Risks, New Welfare, Oxford University Press, Oxford.

- and Stoker, G. (2011) 'The Coalition Programme: A New Vision for Britain or Politics as Usual?', Political Quarterly, 82, 1, 4-27.

Titmuss, R. (1955) 'The Social Division of Welfare', in Essays On the Welfare State, Allen and Unwin, London.

Van Oorschot, W. (2000) 'Who Should Get What, and Why? On Deservingness Criteria and the Conditionality of Solidarity Among the Public', Policy \& Politics, 28(1): 33-48.

Van Oorschot, W. (2006) 'Making the Difference in Social Europe: Deservingness

Perceptions among Citizens of European Welfare States' Journal of European Social Policy, $16,1,23-42$.

WBG (2011a) The Impact on Women of the 2011 Budget, WBG, London.

WBG (2011b) Universal Credit, WBG Briefing, WBG, London.

WBG (2012a) Plan A Has Failed; It Is Time for Plan F, WBG, London.

WBG (2012b) The Impact on Women of the Autumn Financial Statement 2012 and the

Welfare Benefits Uprating Bill 2013, WBG, London.

Williams, F (1989) Social Policy: A Critical Introduction. Issues of Race, Gender and Class, Polity Press,

Yeates, N. et al. (2011) in Defence of Welfare, Social Policy Association, Lincoln. 
Figure 1: Inequality (Gini coefficientss) after Tax and Benefits (OECD)

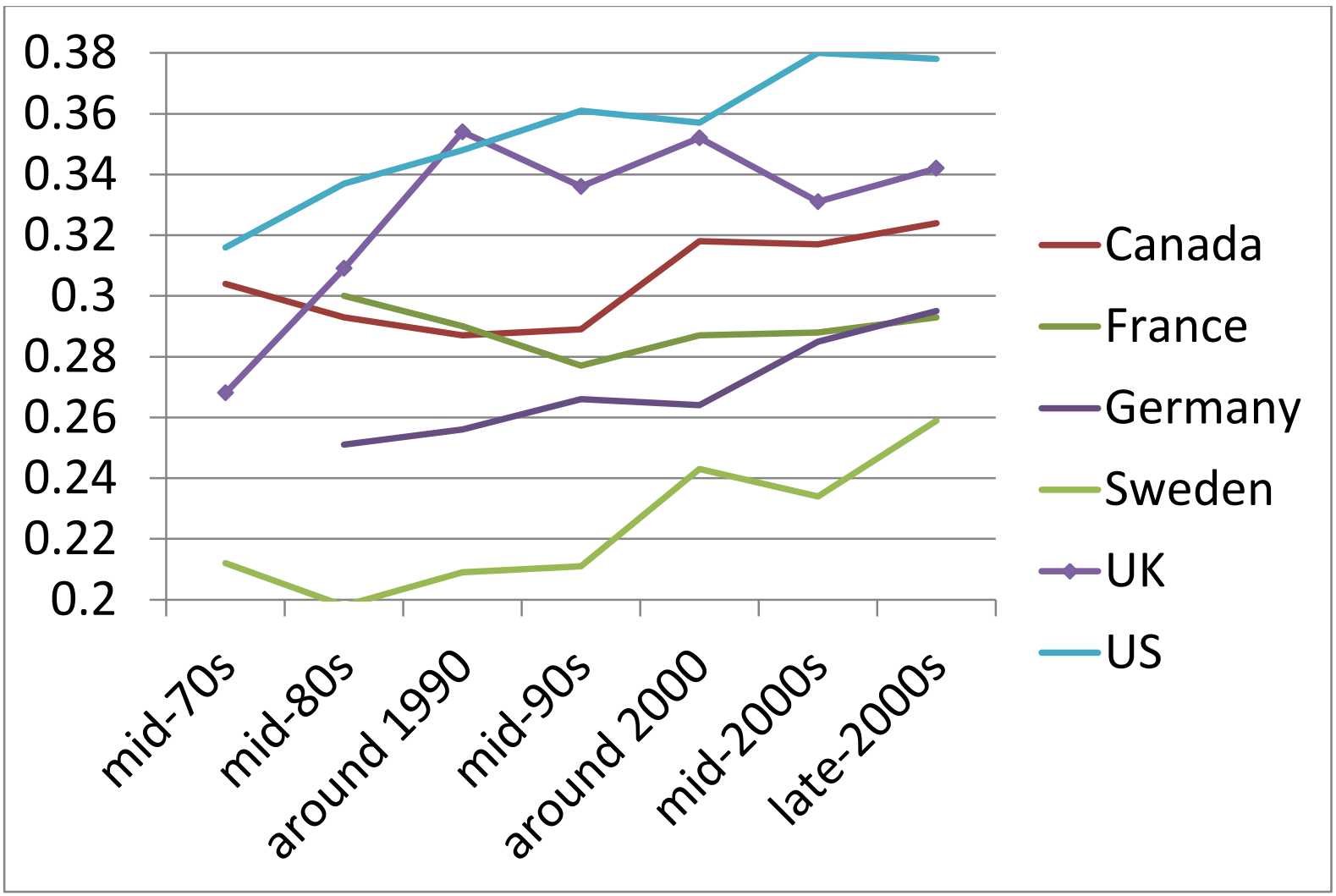

Figure 2: Unemployment and welfare moralism (IMF; BSA)

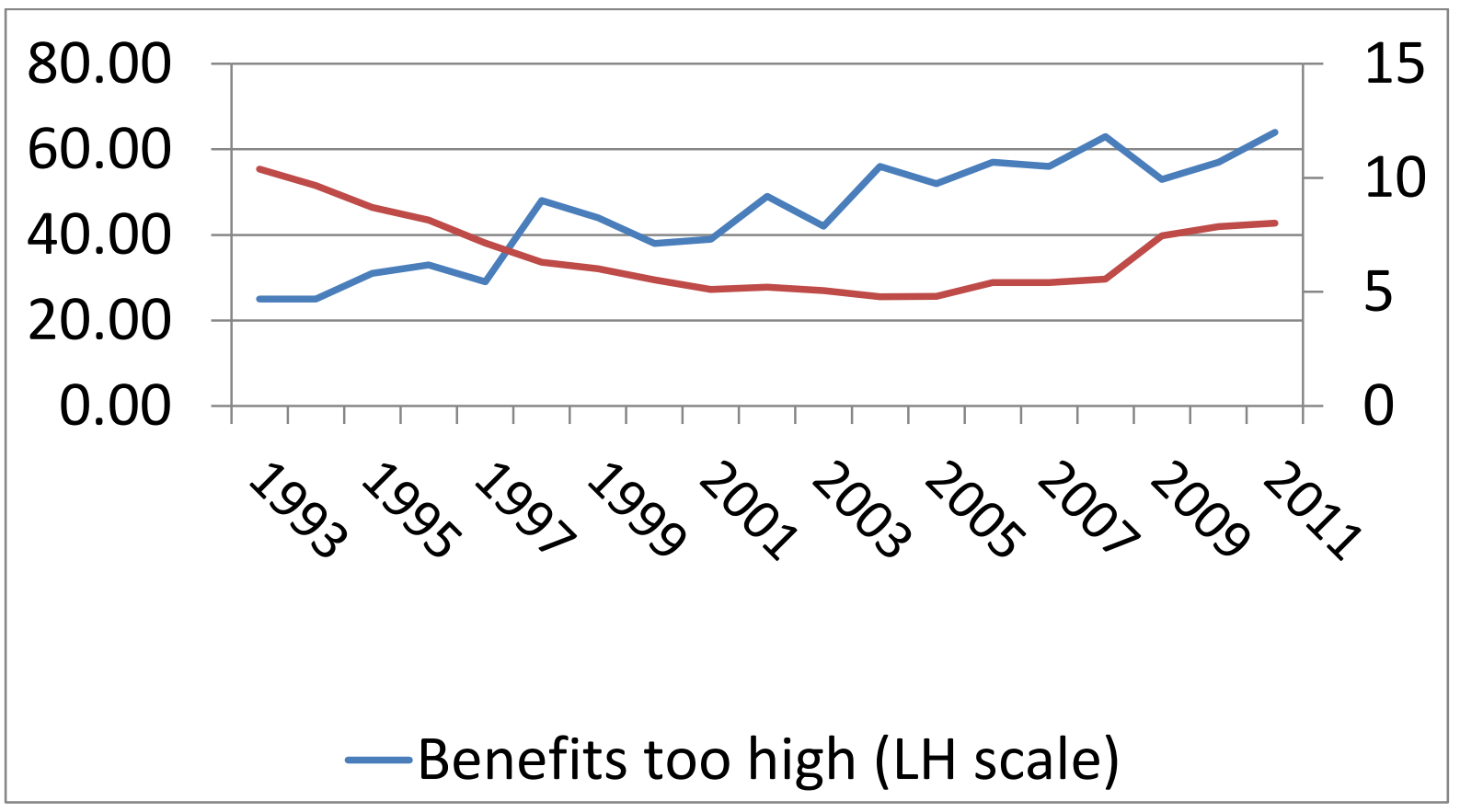

Figure 3: Declining sympathy for the poor (BSA; IFS) 


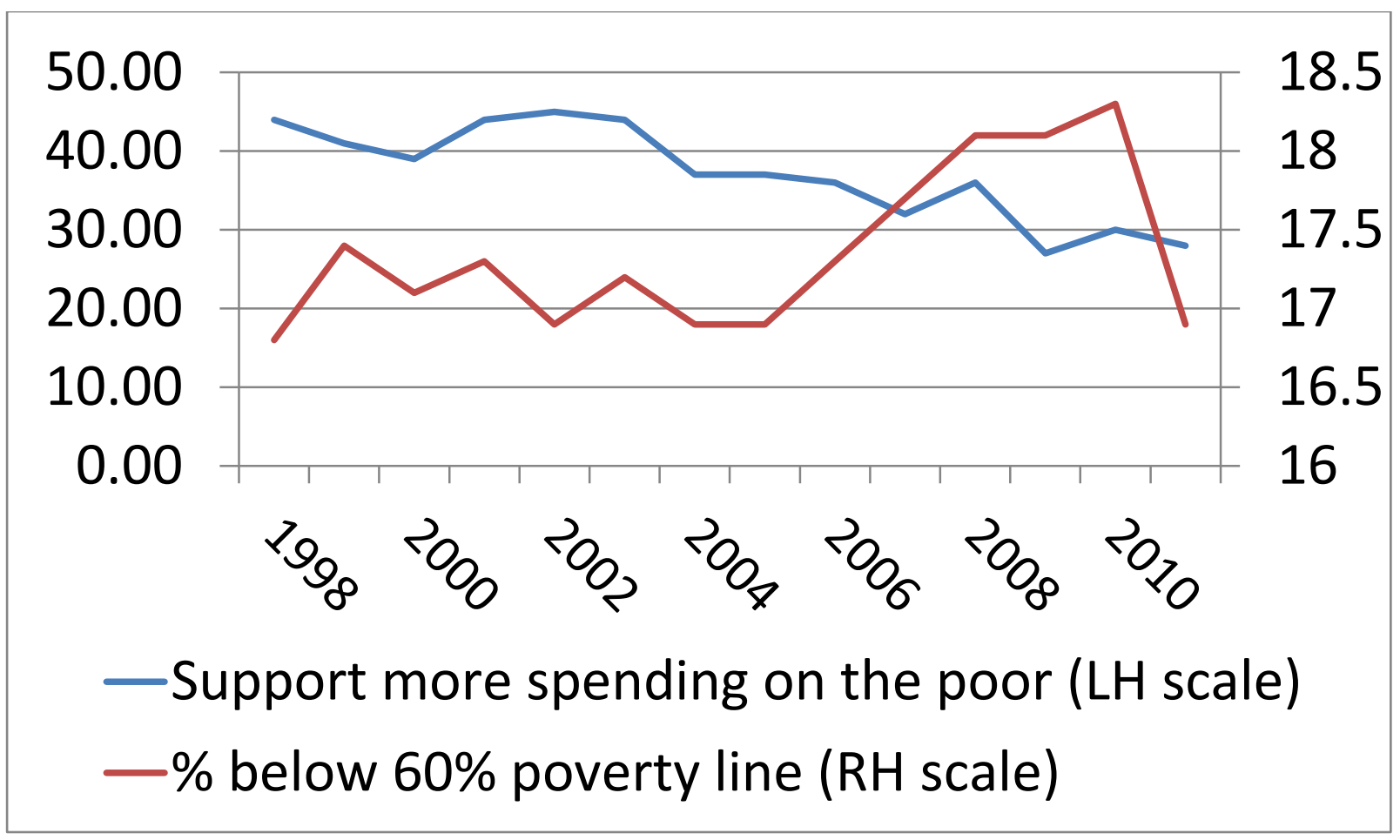

Figure 4: Unemployment (\% Labour Force, IMF WEO) and Media Discourse (Nexis)

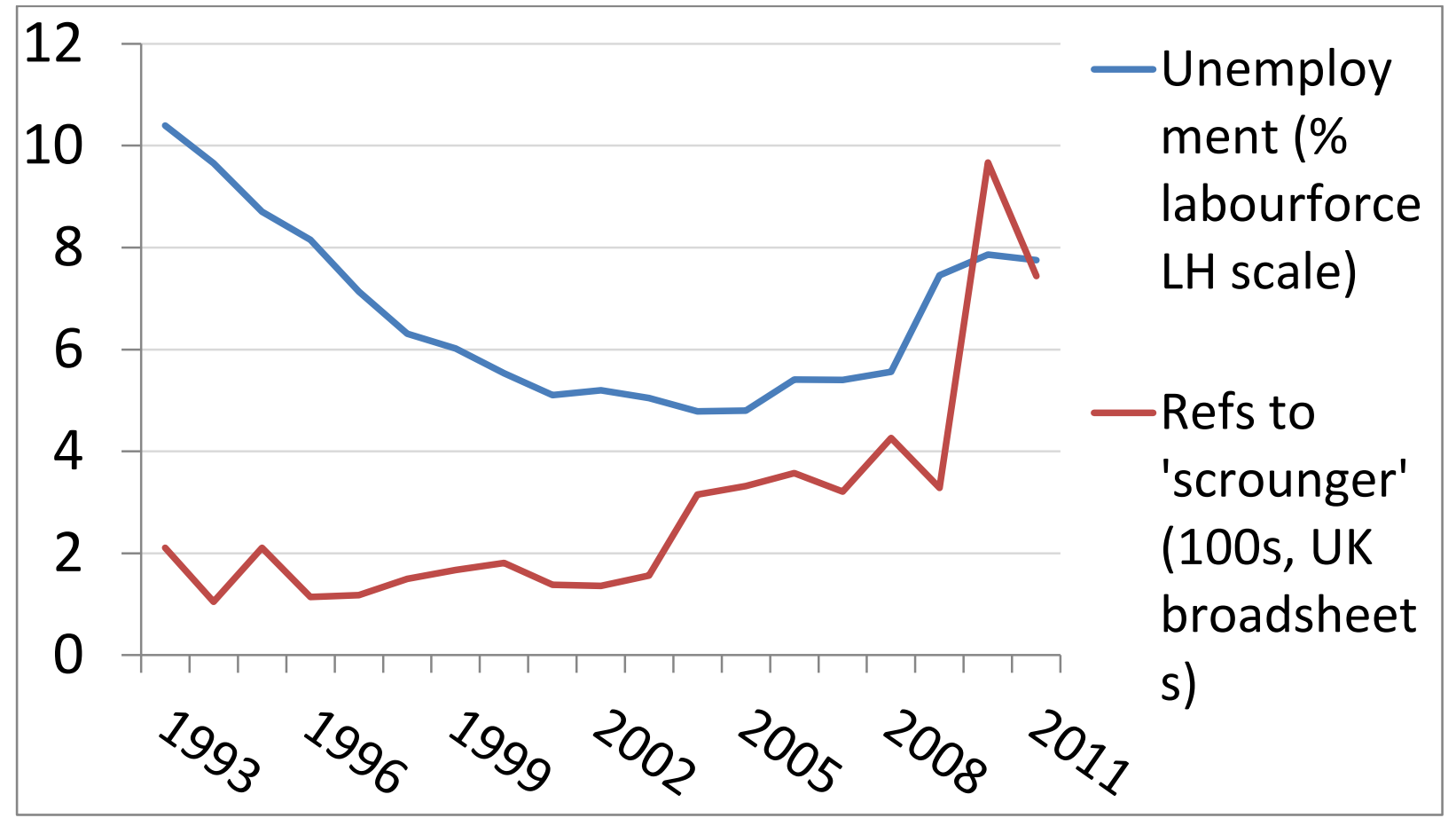


Figure 5: Support for more spending the poor by generation (BSA/Ipsos)

\section{The government should spend more money on welfare benefits for the poor, even if it leads to higher taxes.}

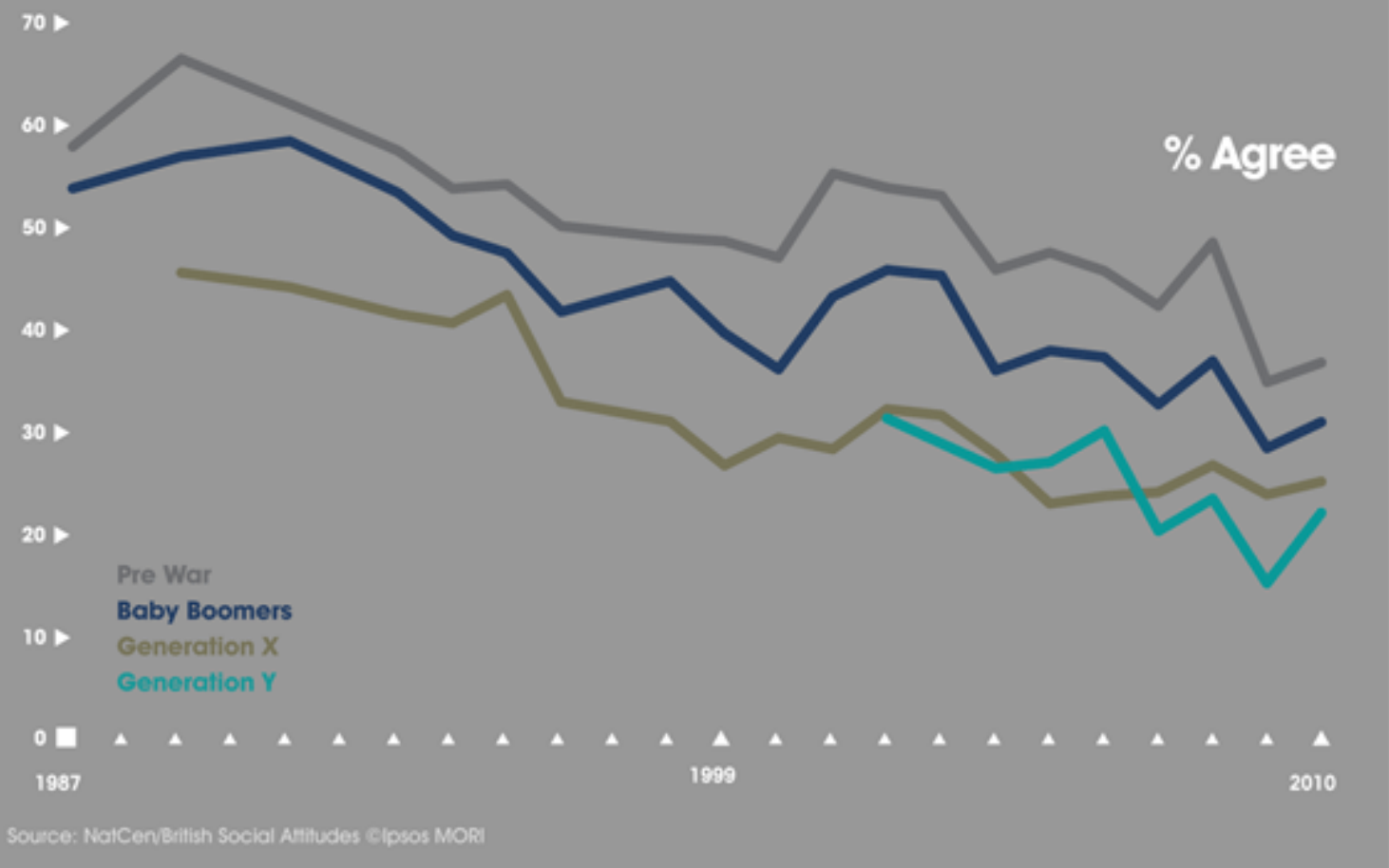

Pre-war: born before 1944

Baby boomer: born 1945-66

Generation X: 1966-79

Generation Y: 1980-92

Figure 6: Three (incompatible) conditions for welfare

\begin{tabular}{|c|c|c|l|}
\hline Inclusive & Effective & Electable & \\
\hline+ & + & - & Stigma/ Cost \\
\hline+ & - & + & Moral curbs \\
\hline- & + & & Labourism \\
\hline
\end{tabular}


Figure 7: Projected age-related spend changes 2010-20 + 2010-60 (\%GDP, EC 2012)

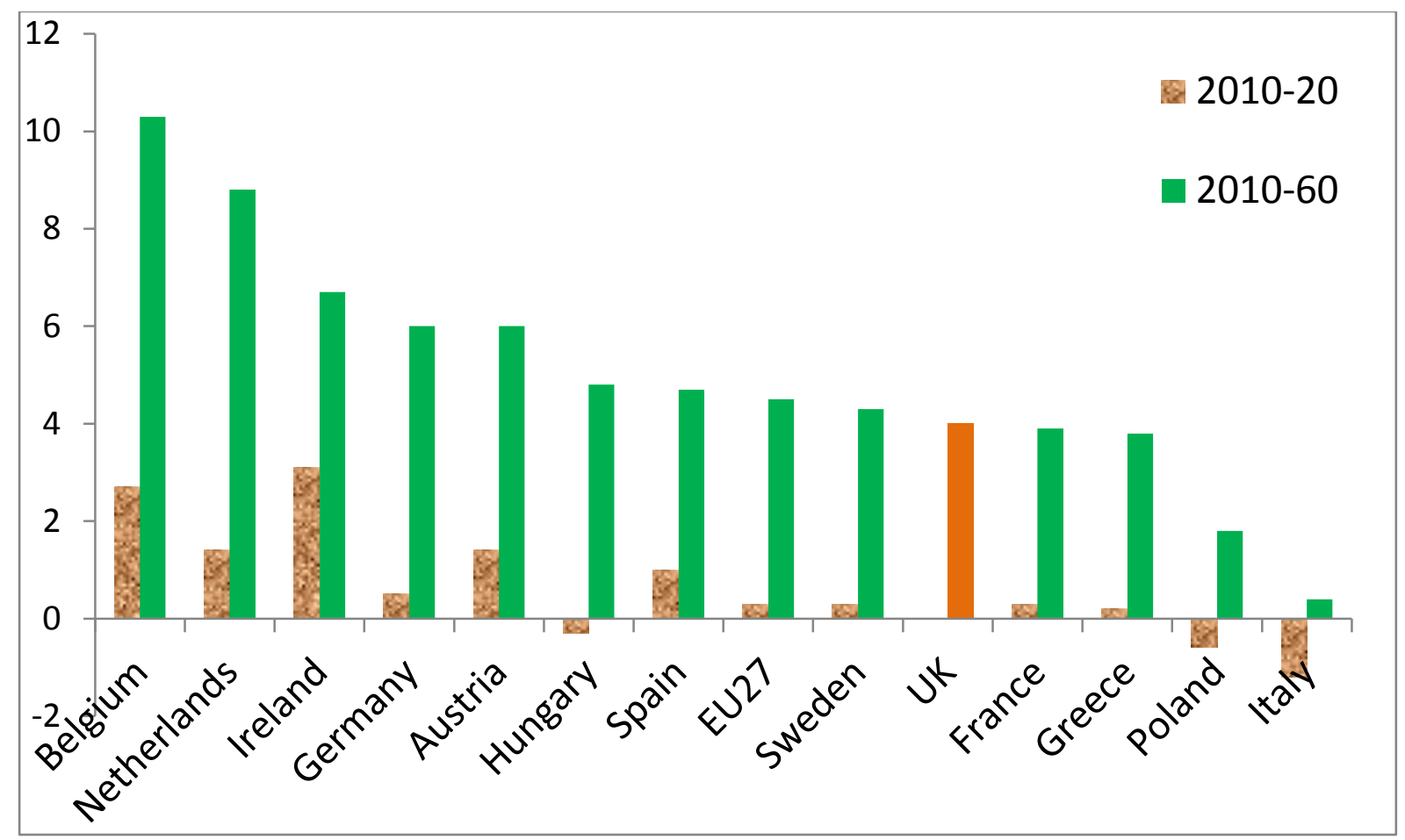

Figure 8: Distinctive stagnation: GDP change \% of 2007 peak (IMF)

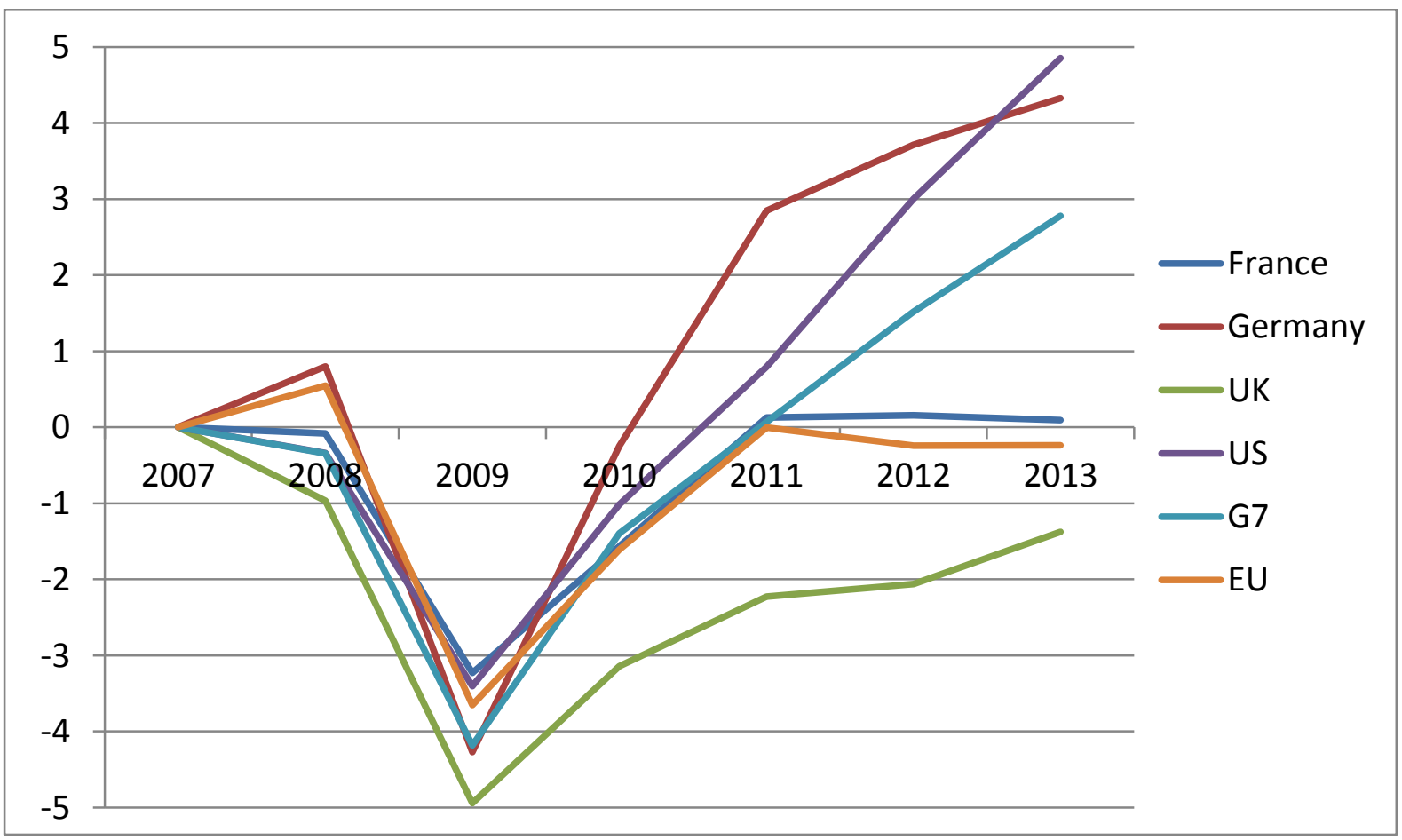


Figure 9: A distinctive spending response: public spending \% GDP (IMF)

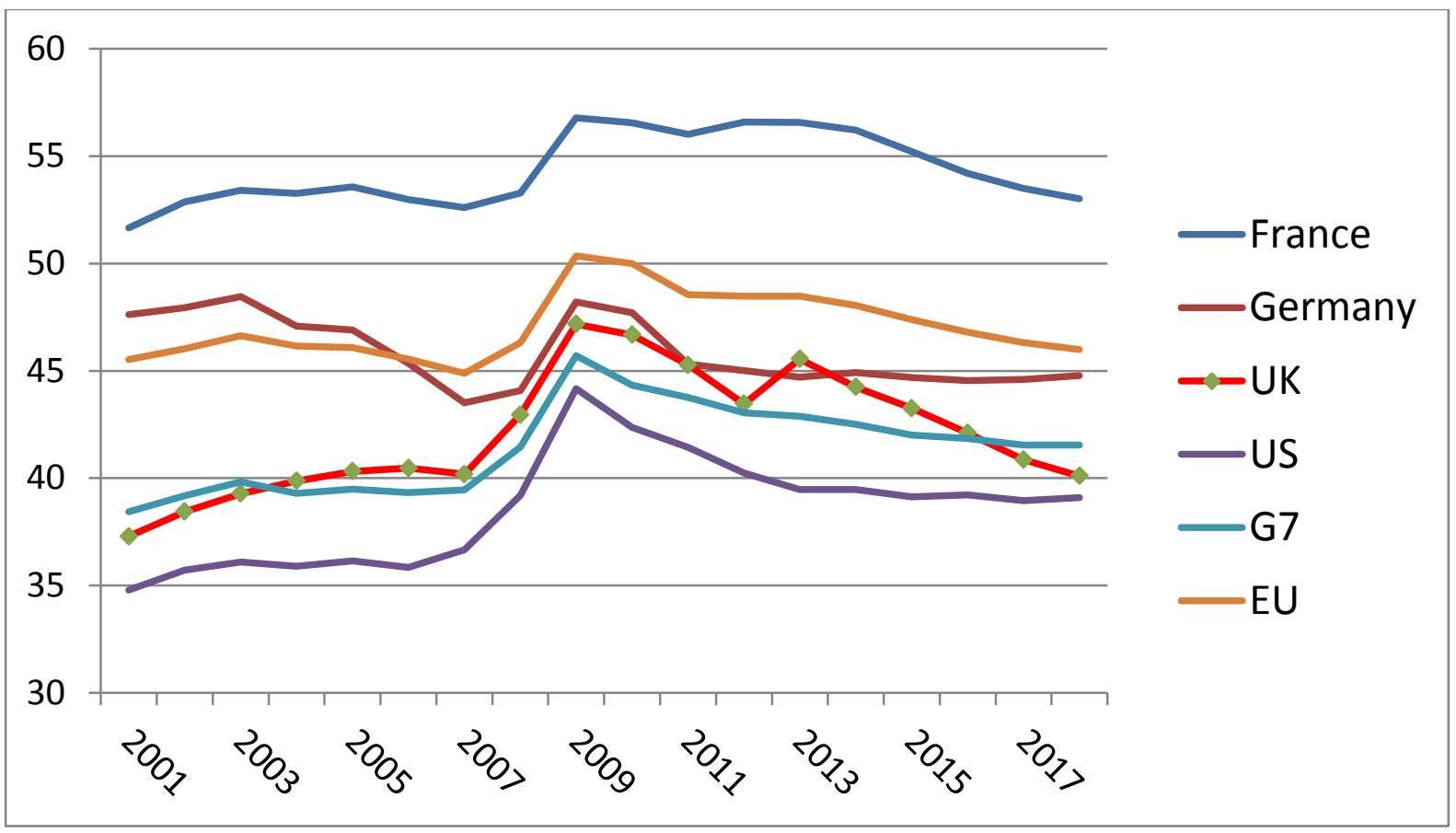

Figure 10: Distinctive incidence: impact of tax/benefit cuts on incomes (2010-15 by decile $\%$; IFS)

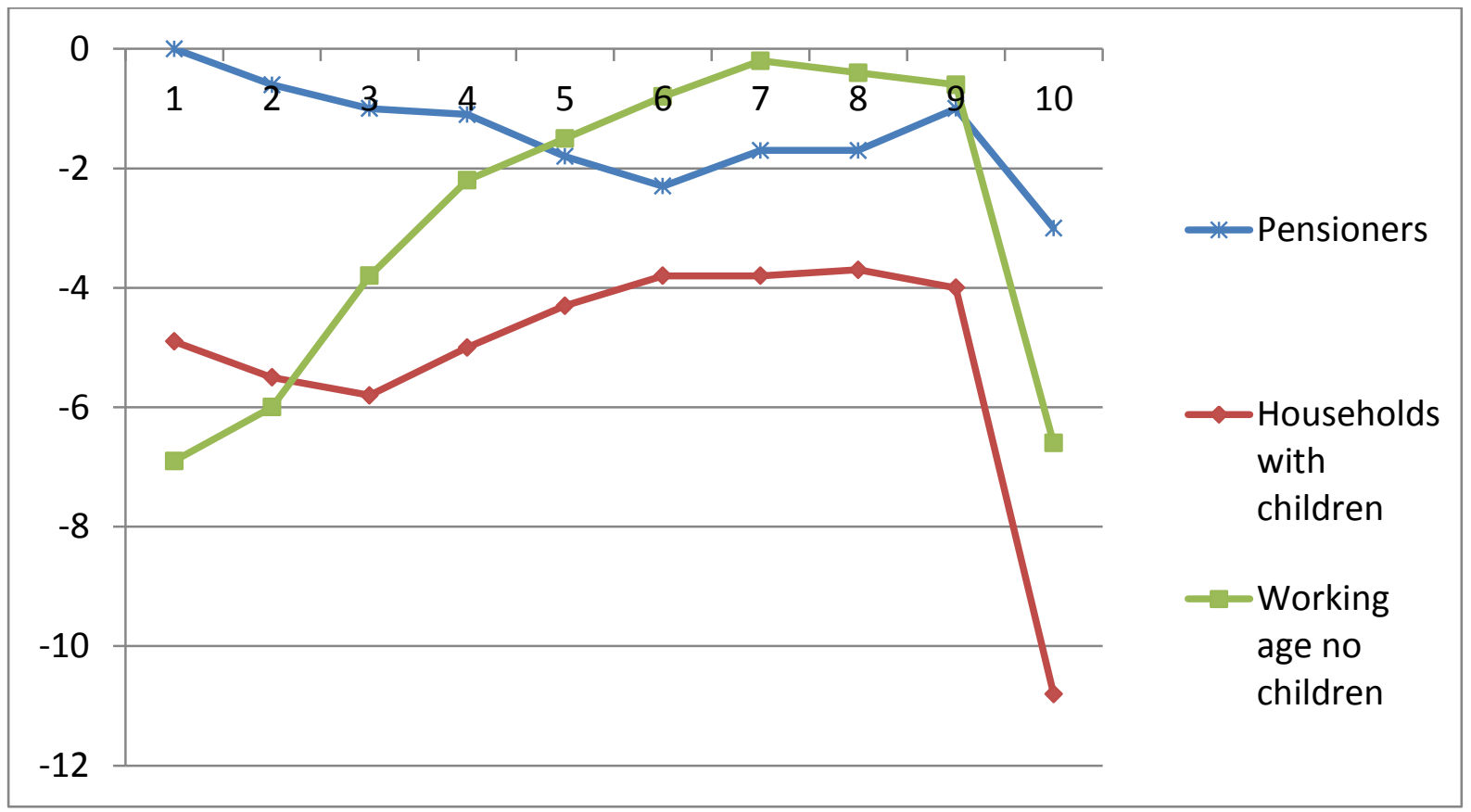


Figure 11: Impact of 2010-11 - 2014-15 changes \% $2010 \mathrm{HH}$ income, quintiles (HMT Budget 2013 T2C)

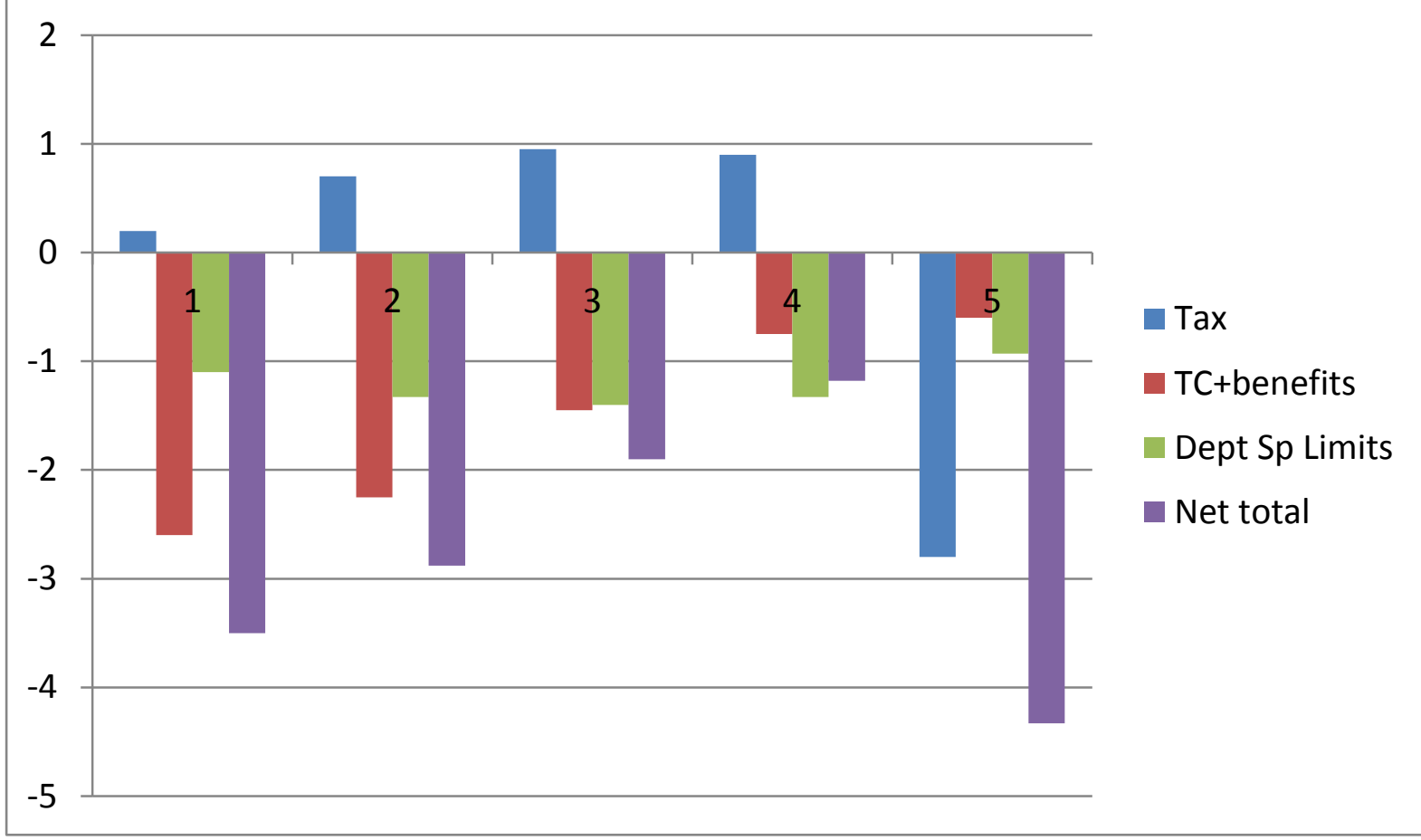


Figure 12: Major attempts to cut state spending and their outcomes

\begin{tabular}{|c|c|c|c|c|}
\hline & $\begin{array}{l}\text { Plans } \\
\% \text { GDP }\end{array}$ & $\begin{array}{l}\text { Achieved } \\
(\% \text { GDP) }\end{array}$ & Outcome & Comment \\
\hline $\begin{array}{l}\text { 1921-2 Geddes } \\
\text { Axe }\end{array}$ & $8 \%$ & $5 \%$ by 1925 & $\begin{array}{l}\text { Local govt. } \\
\text { spending up } \\
4.6 \% \text { by }^{6} 29\end{array}$ & $\begin{array}{l}\text { Central cuts outweighed by } \\
1930\end{array}$ \\
\hline $\begin{array}{l}1931 \text { Nat. } \\
\text { Govt. }\end{array}$ & $4 \%$ & $\begin{array}{l}2.5 \% \text { by } \\
1933\end{array}$ & $\begin{array}{l}\text { Made up by } \\
1936\end{array}$ & $\begin{array}{l}\text { Cost pressures centrally and } \\
\text { locally }\end{array}$ \\
\hline 1975 IMF Loan & $5 \%$ & $\begin{array}{l}1.5 \% \text { by } \\
\text { ' } 79, \text { local } \\
\text { govt }\end{array}$ & $\begin{array}{l}\text { Made up: } \\
\text { rises during } \\
1983 \\
\text { recession }\end{array}$ & Mainly loc. govt. \\
\hline $\begin{array}{l}\text { 1980-90 } \\
\text { Thatcher }\end{array}$ & $\begin{array}{l}\text { 'rolling back } \\
\text { the state' } 8 \%\end{array}$ & $\begin{array}{l}5.4 \% \text { by } \\
1990\end{array}$ & $\begin{array}{l}3 \% \text { made up } \\
\text { by } 1993\end{array}$ & Election spending/ 1991crisis \\
\hline $\begin{array}{l}\text { 1993-9 Major/ } \\
\text { Blair }\end{array}$ & $3.8 \%$ & 4\% by 1997 & $\begin{array}{l}\text { Further } 1 \% \text { in } \\
\text { NL } 1 \text { st } 2 \text { yrs }\end{array}$ & Made up under NL by 2005 \\
\hline 2007-10 Brown & $\begin{array}{l}1.4 \% \\
\text { (efficiency } \\
\text { savings) }\end{array}$ & $\begin{array}{l}0.4 \% \text { by } \\
2009\end{array}$ & $\begin{array}{l}67 \% \text { these } \\
\text { service cuts } \\
\text { not efficiency } \\
\text { savings }\end{array}$ & $\begin{array}{l}\text { Stimulus package; coalition } \\
\text { reforms }\end{array}$ \\
\hline
\end{tabular}

